\title{
Numerical analysis of reducing tunneling effect on viaduct piles foundation by jet grouted wall
}

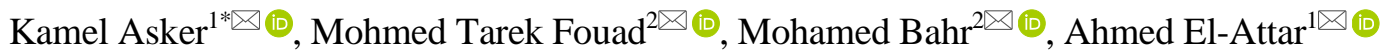 \\ ${ }^{1}$ Higher Technological Institute, Cairo, PO Box 228, Egypt \\ ${ }^{2}$ Al-Azhar University, Cairo, 11751, Egypt \\ *Corresponding author: e-mail kamelasker2004@hti.edu.eg, tel. +201003601519
}

\begin{abstract}
Purpose. The target of this study is divided into two parts. The first part is concerned with capability of numerical model to simulate the tunneling process. The second part is related to studying the interaction mechanism between the tunnel, protection technique, and soil. This study themes are investigated by analyzing different protection technique configuration, considering different stiffness of the grouted wall, and applying different interface coefficient between the wall and the soil.

Methods. The method used in this study to check the accuracy of the proposed numerical model is 4-D ABAQUS program. The typical excavation of a tunnel is simulated step by step with an assumed rate of tunnel advancement $(0.5$ to $1.5 \mathrm{~m} / \mathrm{hr})$. The soil material utilized in this model is elastic perfectly plastic (the Mohr-Coulomb criterion), while elastic material is modeled as solid element (S4R) adopted for lining, grouting, filling gaps, shielding, constructing piles, and jet grouted wall.

Findings. Results showed that the closer jet grouting to the tunnel with embedded length of 1.5 times tunnel diameter, the better effect on reducing the lateral deformation and bending moment generated on piles. Otherwise, increasing wall thickness more than double grouted column diameter would not affect its shielding efficiency. Furthermore, either increasing or decreasing friction coefficient even if rough between the grouted wall and soil had no effect on the pile behavior. Additionally, applying Mohr-Coulomb criteria for grouted wall with high stiffness allowed realistic response of the pile group.

Originality. Capability of the proposed model is verified by back analysis of Changsha Subway Line 1 project, where the shield tunnel would be constructed near existing pile groups of L off-ramp of the Xinzhong Road viaduct.

Practical implications. Increasing grouted wall configuration is more effective than mechanical properties or its interface coefficient with surrounded soil in mitigating tunneling effect on nearby piles.
\end{abstract}

Keywords: tunneling, jet grouting, gield measurements, ABAQUS, Changsha Subway Line 1

\section{Introduction}

Tunnel construction would cause soil movements that may induce additional axial loads, bending moments and deformations on adjacent foundations. If tunneling-induced pile responses are not taken account in the design, the structural integrity and serviceability of the piles may be compromised. To investigate the influence of tunneling on ground and nearby pile foundations, Xiang et al. [1] studied the effect of tunneling in clayey sandy soil on urban piled overpass structures of Beijing station. Bilotta and Russo [2] conducted a series of three-dimensional finite element analyses to explore the use of rows of closely spaced piles in mitigating the tunneling-induced ground movements.

$\mathrm{Ng}$ et al. [3] found that, tunnel excavation close to existing pile toes induced about twice as large pile head settlement, when the tunnel was located near the mid-depth of the pile shaft. Zou and Xu [4] carried out 3D numerical simulation to investigate the mitigation effects of the separation pile and diaphragm wall to tunnel-induced ground movements, considering the effects of soil stiffness variation at small strain. The length of the pile wall was highlighted to be the main influential factors. Bai et al. [5] adopted three protection techniques to separate the buildings from tunneling effect.

Nematollahi and Dias [6] reported that tunneling near an existing pile could cause considerable changes in the pile's vertical movements, the induced axial loads and bending moments. Fu et al. [7] evaluated the effectiveness of underground jet-grouted partition wall in mitigating the effects of shield-tunnel construction on existing piled structures through numerical analysis and field monitoring. ELAttar [8] carried out 3D finite element analysis to investigate the effect of the different grouting shapes such as jet grouting wall placed at or below tunnel springline, to reduce the tunneling effect on adjacent pile. Recently Li et al. [9], compa- 
ring various protective schemes, selected and analyzed the suitable deep-hole grouting scheme and pile foundation underpinning scheme.

The case history applied in this research is the project of the Changsha Subway Line 1 where a tunnel was constructed near existing pile groups of L off-ramp of the Xinzhong Road viaduct and grouted wall was used to protect the viaduct piles foundations. This case history was modeled using 4-D ABAQUS [10] program, and the accuracy of the proposed model was verified based on the recorded field data. To minimize the effect of tunneling on an existing piles foundation, a geometrical parametric study was carried out taking into consideration the variation of grouted wall location, dimensions, and its mechanical properties.

\section{Problem statement}

Two tunnels located closely to the L off-ramp of the Xinzhong Road viaduct in the project of the Changsha Subway Line 1, are shown in Figure 1.

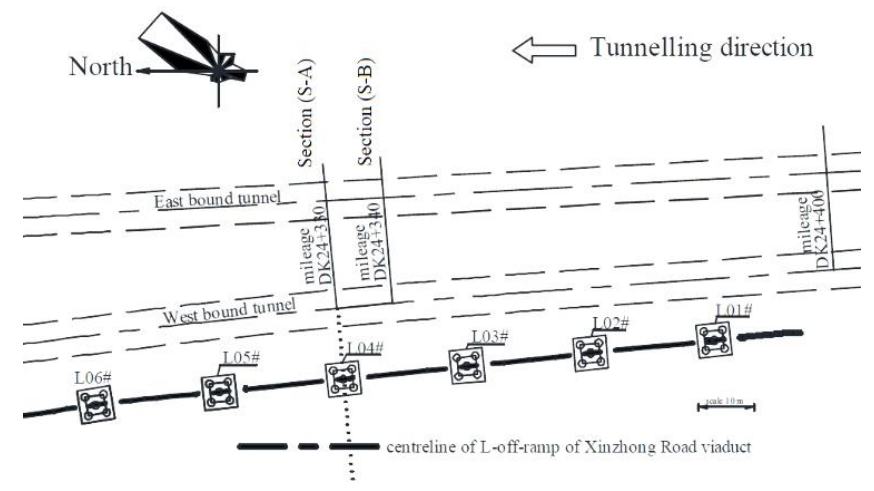

Figure 1. Plane view of the Changsha Subway Line 1 passing through L off-ramp of the Xinzhong Road viaduct [7]

The tunnels are driven by two earth pressure balance (EPB) machines with excavated diameter $6.25 \mathrm{~m}$ and $12.50 \mathrm{~m}$ in length. The two tunnels are located at $21.5 \mathrm{~m}$ below the ground surface and spaced at $18.70 \mathrm{~m}$. The shield tunnel is driven in the clayey sandy gravel with pebble ground which is overlain by silty clay followed by plain fill up to the ground surface. The ground water table is located at a depth ranging from 7 to $8 \mathrm{~m}$ below the ground surface in this area. Table 1 summarizes the mechanical parameters of soil layers used for analysis in this study.

\section{Table 1. Mechanical properties of soil [7]}

\begin{tabular}{cccccccc}
\hline Layer & $\begin{array}{c}\text { Thick- } \\
\text { ness (m) }\end{array}$ & $\gamma, \mathrm{kN} / \mathrm{m}^{3}$ & $\varphi,{ }^{\circ}$ & $c, \mathrm{kPa}$ & $E, \mathrm{kN} / \mathrm{m}^{2}$ & $v$ & $\Psi,{ }^{\circ}$ \\
\hline Plain & $0.00-$ & 19 & 17 & 40 & 10000 & 0.40 & 0 \\
$\begin{array}{c}\text { Fill } \\
3.50\end{array}$ & & & & & & \\
$\begin{array}{c}\text { Silty } \\
\text { Clay }\end{array}$ & $\begin{array}{c}3.50- \\
6.80\end{array}$ & 20 & 20 & 65 & 30000 & 0.38 & 0 \\
$\begin{array}{c}\text { Clayey } \\
\text { Sandy }\end{array}$ & $\begin{array}{c}6.80- \\
\text { extend }\end{array}$ & 22 & 36 & 10 & 50000 & 0.35 & 6 \\
\hline
\end{tabular}

To minimize the effect of tunneling on the pier, three rows of jet grouted columns were installed to form an underground partition wall at least $4 \mathrm{~m}$ length beyond piles centerlines in both directions to protect the pier from tunneling process. The diameter of the jet-grouted columns $\left(d_{g c}\right)$ is $0.8 \mathrm{~m}$ and their axis spacing is $0.5 \mathrm{~m}$. That means there is always about $0.3 \mathrm{~m}$ jet-grouted column body interlocked with the adjacent one. As a result, the jet-grouted columns can act as an underground wall to partition off the soil movements.

Figure 2 shows the typical section of the tunnel and its relationship with the Pier L04. The pier is located at DK24 +330 founded by four friction-cum-end bearing piles. Each pile has a diameter of $1.2 \mathrm{~m}$ and is enlarged to $1.8 \mathrm{~m}$ at the end. The distance of the nearest pile to the tunnel is $6.20 \mathrm{~m}$.
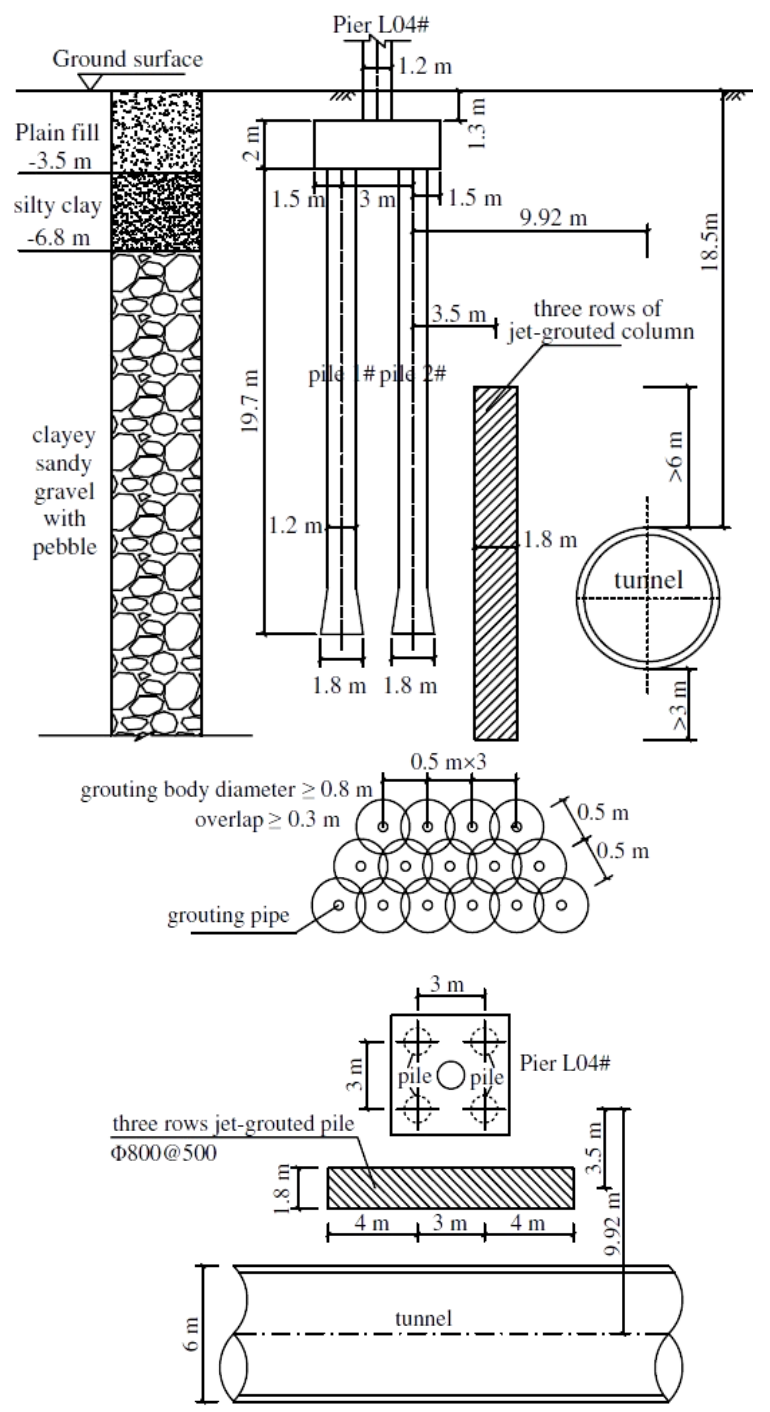

Figure 2. Layout of Pier L04\#, the jet-grouted partition wall, and the tunnel [7]

To evaluate the effectiveness of the jet-grouted wall in mitigating the ground movements, extensive measurements were carried out to monitor the response of the ground during the construction of the shield tunnel. Table 2 summarizes the parameters of tunnels, piles and jet grouted wall. Settlement observation points were installed along the transverse section $(\mathrm{S}-\mathrm{A})$ where Pier L04\# is protected by the jet-grouted partition wall, and another comparative transverse section (S-B) 10 m away to the south (without partition wall) was monitored as well.

\section{Numerical model}

To investigate the tunneling effect on the induced ground response, a three- dimensional model with circular tunnel configuration was developed using the general-purpose finite element suite, ABAQUS. 
Table 2. Tunnel, piles, and jet grouted wall properties [7]

\begin{tabular}{|c|c|c|c|c|c|}
\hline \multirow[t]{2}{*}{$\underset{E}{\stackrel{\Xi}{\Xi}}$} & 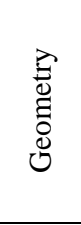 & \multicolumn{2}{|c|}{$\begin{array}{l}\text { Inner dia. } \\
\text { Lining thickness } \\
\text { Shield thickness } \\
\text { Gap thickness } \\
\text { Grouting thickness }\end{array}$} & \multicolumn{2}{|c|}{$\begin{array}{c}5.40 \mathrm{~m} \\
0.30 \mathrm{~m} \\
50 \mathrm{~mm} \\
75 \mathrm{~mm} \\
125 \mathrm{~mm} \\
\end{array}$} \\
\hline & 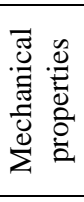 & $\begin{array}{c}\text { Type } \\
\text { Lining } \\
\text { Shield } \\
\text { Gap } \\
\text { Grouting } \\
\end{array}$ & $\begin{array}{c}E, \mathrm{kN} / \mathrm{m}^{2} \\
1.40 \times 10^{7} \\
2.10 \times 10^{8} \\
1000 \\
\text { Vary } \\
\end{array}$ & $\begin{array}{c}\gamma, \mathrm{kN} / \mathrm{m}^{3} \\
25 \\
78 \\
- \\
25 \\
\end{array}$ & $\begin{array}{c}v \\
0.15 \\
0.3 \\
0.3 \\
0.15 \\
\end{array}$ \\
\hline & $\begin{array}{l}\text { and } \\
\text { cap }\end{array}$ & Mechanical & $3 \times 10^{7}$ & 25 & 0.2 \\
\hline & $\begin{array}{l}\text { outed } \\
\text { all }\end{array}$ & properties & $2 \times 10^{6}$ & 25 & 0.2 \\
\hline
\end{tabular}

The choice of adequate mesh dimensions should not affect the tunneling process. Moller [11] recommended the vertical boundaries to be 4 to 5 times the tunnel diameter $(D)$ measured from the tunnel centerline, and the horizontal boundaries to be 2 to $3 \mathrm{D}$ measured from the tunnel centerline. Accordingly, the scope of the model was chosen to be $100 \mathrm{~m}$ in transverse direction, $60 \mathrm{~m}$ in longitudinal direction, and $45 \mathrm{~m}$ in depth. Figures 3 and 4 show the three-dimensional model and its details considered in this study respectively.

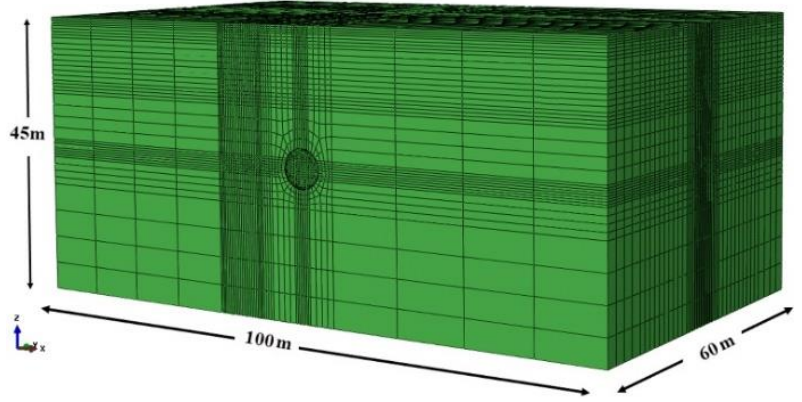

Figure 3. The three-dimensional model

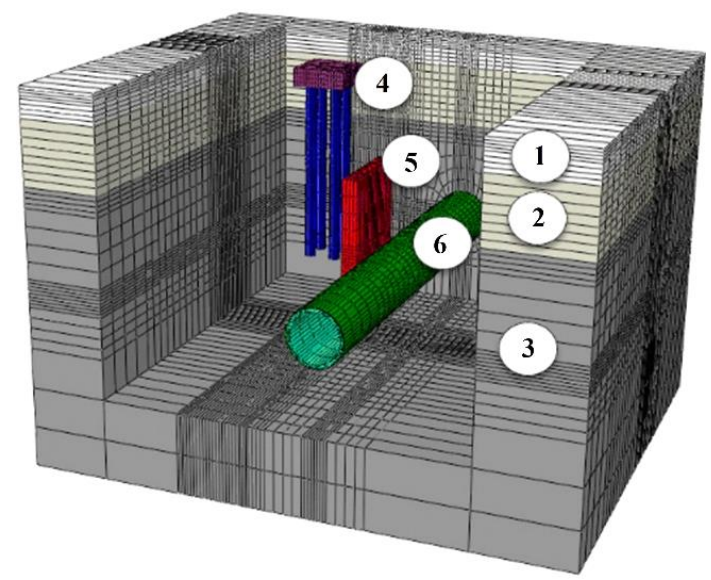

Figure 4. Details for numerical model: 1 - plain fill layer; 2 - silty clay layer; 3 -clayey sandy gravel layer; 4 -piles and piles cap; 5 -jet grouted wall; 6 - tunnel component

Soil section with three distinct layers modeled as solid element (C3D8RP), the material utilized in this model as elastic-perfectly plastic (the Mohr-Coulomb criterion), and an elastic material modeled as solid element (S4R) are adopted for lining, grouting, gap, shield, piles and jet grouted wall. The effective face pressure exceeds the pore water pressure by fraction of effective over burden pressure. This fraction is taken as $(100 \mathrm{kPa})$.

The grouting pressure should be always greater than the hydrostatic pressure which is selected equal to the soil total stress at the springline $(100 \mathrm{kPa})$.

The typical excavation of tunneling activities is simulated step by step with assumed rate of tunnel advancement $(0.5$ to $1.5 \mathrm{~m} / \mathrm{hr}$ ). This simultaneous of tunneling is as follow:

- removing length of soil equal to $(1.5 \mathrm{~m} / \mathrm{step})$ and conducting TBM with surrounding gap and applying excess face pressure periodically to sustain the shield length of $9 \mathrm{~m}$;

- deactivating the TBM with gap element and face pressure;

- activating lining and grout element taking into consideration the setting time of grout.

The grout initial stiffness is $(1000 \mathrm{kPa})$. This stiffness increases with the rate depending on the time passing from the liquid state to the hardening state. It also relates to the compression strength by the developed empirical formula (Equation 1) ACI-Building-Code [12]:

$$
E=4730 \cdot \sqrt{f_{c}}, \mathrm{kPa} \text {. }
$$

\section{Analysis and results of numerical model}

Results of finite element study are compared with the field monitoring data to evaluate the capability of the proposed model and to simulate complex interaction between soil, piles, jet grouted wall and tunnel.

\subsection{Prediction of field deformation}

The observed deformation trend of the soil was well depicted by the ABAQUS model before and after the executed tunnel as shown in Figures 5 and 6 respectively. It can be noted that the soil deformation increases towards the tunnel vicinity as a result of tunnel overcut.
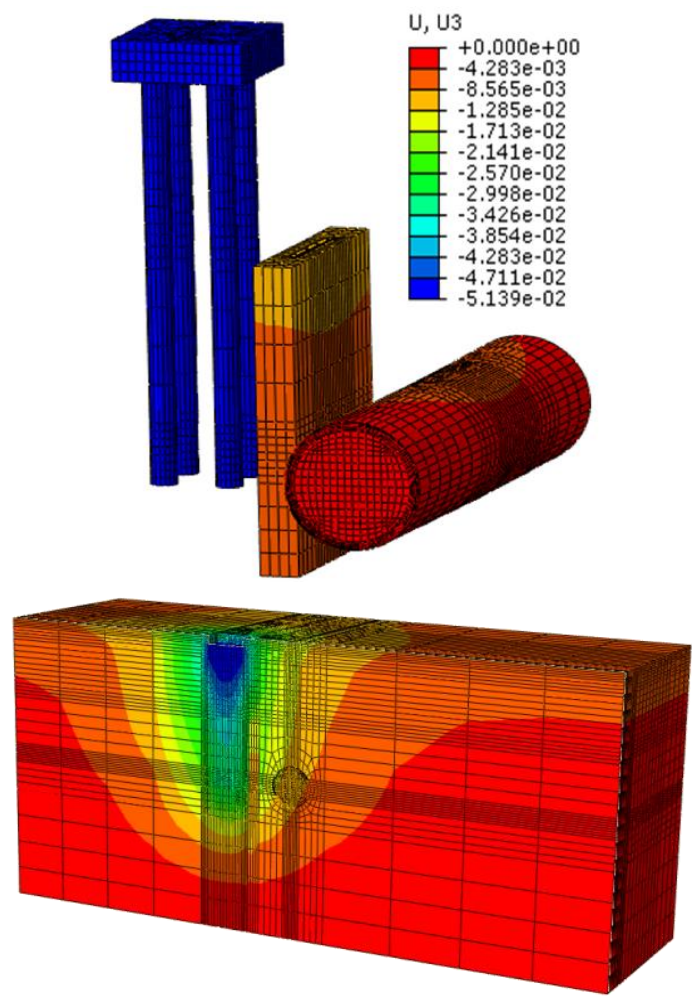

Figure 5. Vertical deformation before tunneling 

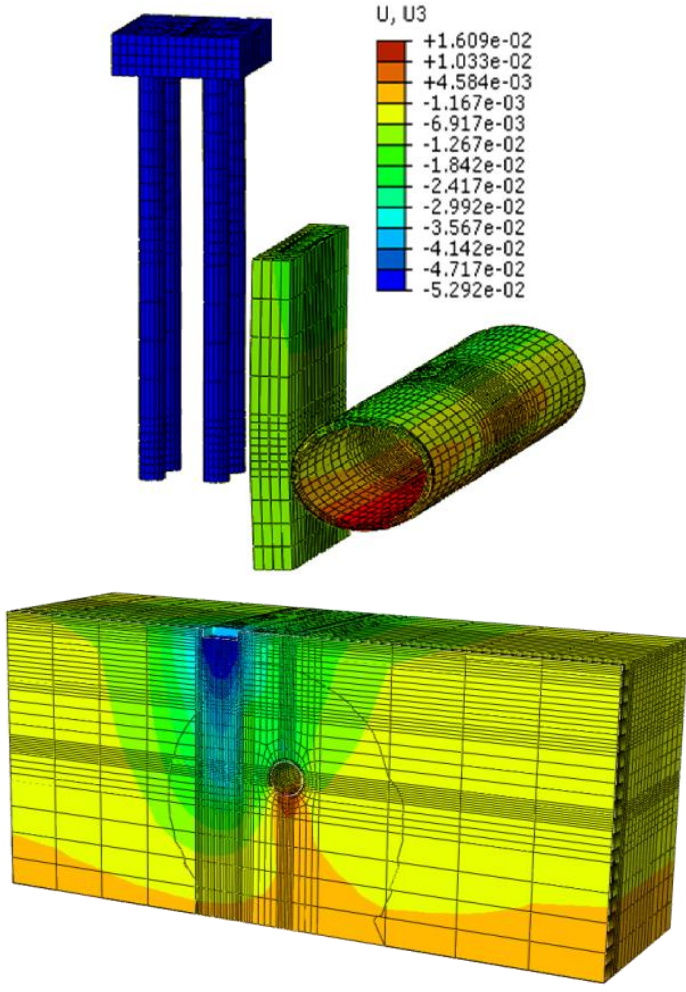

Figure 6. Vertical deformation after tunneling

\subsection{Settlement trough}

The induced surface settlement is estimated for the transverse monitored section (S-A) in Figure 1 after running of the tunnel. The results indicate that the computed ground surface displacement is about 5\% less than that of field displacement as shown in Figure 7. The settlement trough as estimated from another numerical model adopted by $\mathrm{Fu}$ et al. [7] is also presented in the same Figure. In addition, the ordinate of the surface settlement trough is not symmetrical about the tunnel vicinity due to the existence of piles foundation of viaduct in the global interaction system.

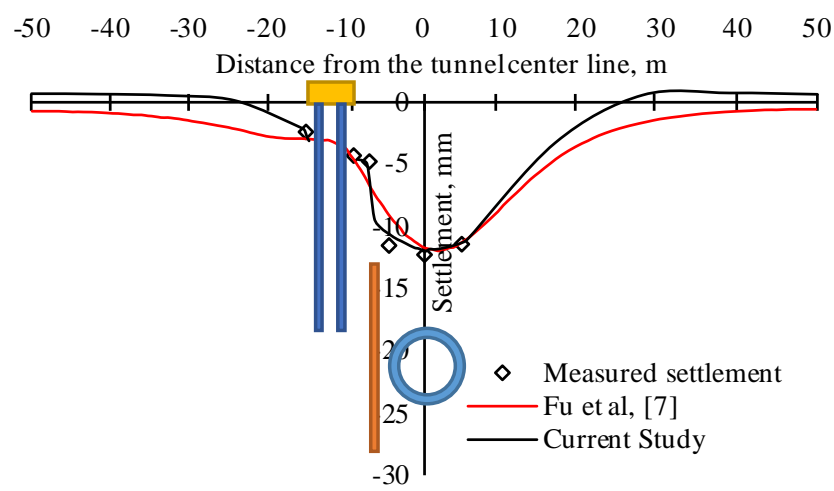

Figure 7. Induced surface settlement trough at section $(S-A)$

Generally, it is obvious that the comparison indicated good signs of agreement between the computed ordinates and the measured values. However, the results showed ground heave after distance of $25 \mathrm{~m}$ far from the tunnel centerline, field data being only available for a distance less than $20 \mathrm{~m}$.

The induced surface settlement estimated for the transverse monitored section ( $\mathrm{S}-\mathrm{B})$ after running of the tunnel is shown in Figure 8.

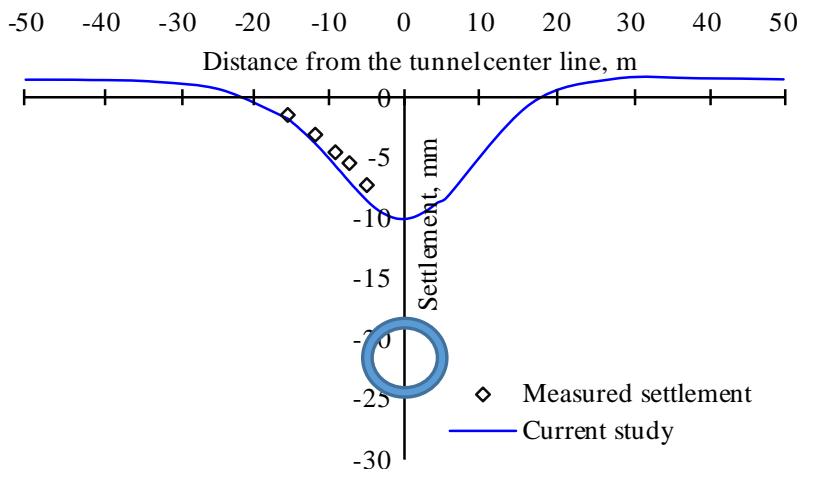

Figure 8. Induced surface settlement trough at section (S-B)

The results indicate that the computed ground surface displacement is about $9 \%$ more than that of observed field displacement.

\section{Parametric study}

Figures 9 and 10 show a schematic diagram and working principles for various parameters of the jet grouted wall used in the suggested model to fulfill the objectives of the study. Parametric studies were carried out to investigate the most effective schemes of jet grouted wall with the length $\left(\mathrm{d}_{\mathrm{jet}}\right)$, location $\left(X_{j e t}\right)$, thickness $\left(B_{j e t}\right)$, mechanical properties of grouted wall $\left(E_{\text {grout }}\right)$ and friction coefficient $\left(C_{f}\right)$ of the surrounding soil to minimize the tunneling effect on piles foundation as an alternative scheme.

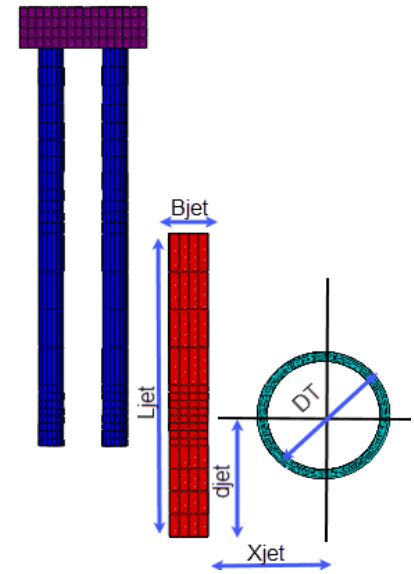

Figure 9. Geometric profile of pile-grout-tunnel interaction

\section{Results and discussion}

The alternative schemes are investigated based on the same tunnel aspects used in the verified case history. These schemes are compared with non-grouted wall case and non-protective technique used, to estimate the efficiency of each scheme of the jet grouted wall. Results of numerical models clarified the effect of different protection schemes on surficial settlement for ground surface and axial force, bending moment, vertical and horizontal deformations for the nearest pile due to tunneling process.

\subsection{Effect of the jet grouted wall length and location relative to the tunnel diameter}

The effect of grouted wall location $\left(X_{\text {jet }}\right)$ relative to the tunnel diameter $0.5 D_{T}, 0.8 D_{T}, 1 D_{T}$ (close to the tunnel, mid-way between the tunnel and the pile and close to the pile) respectively is examined by considering two different grouted wall lengths $\left(d_{j e t}\right)$ relative to tunnel diameter $1 D_{T}$ and $1.5 D_{T}(6 \mathrm{~m}$ below springline and $9 \mathrm{~m}$ below springline) respectively to study the effect of its configuration due to tunneling. 


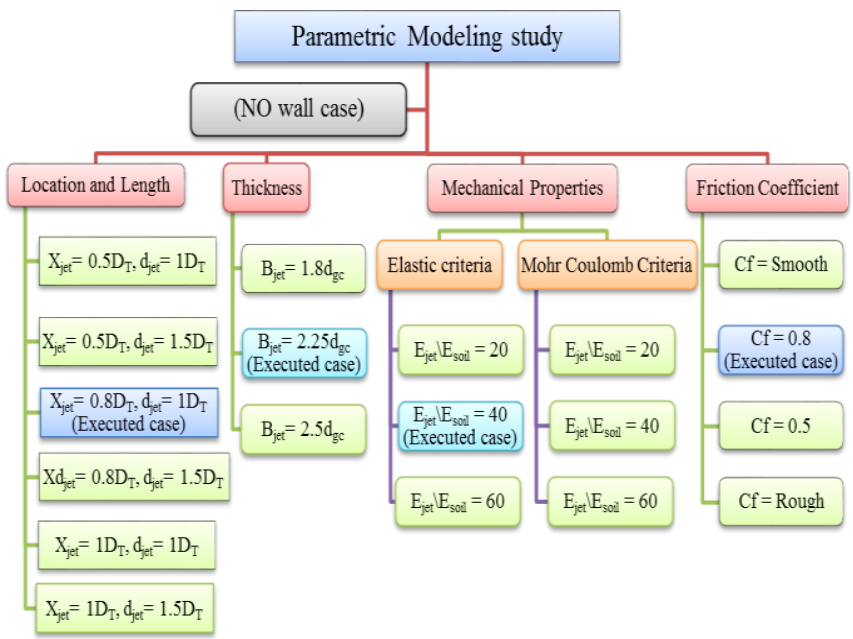

Figure 10. Framework of investigated parameters used in FE analysis: $D_{T}$-outer tunnel diameter $(6.25 \mathrm{~m}) ; B_{j e t}-$ thickness of grouted wall; $d_{j e t}-$ jet grout length below tunnel, CL; $d_{g c}-$ grouted column diameter $(0.8 \mathrm{~m})$; $X_{j e t}-$ distance from grouted wall and tunnel, $C L: L_{j e t-}$ height of grout wall

Figure 11 represents the induced surface settlement trough at the center line of the pile cap in section (S-A) as shown in Figure 1 for different offset values and lengths of the grouted wall due to tunneling. The Figure indicates that, for the long-grouted wall length $\left(d_{j e t}=1.5 D_{T}\right)$, the soil settles less than other cases of using different lengths of the grouted wall. In addition, the surface settlement for the grouted wall length $\left(d_{j e t}\right)$ below the tunnel springline of about $1 D_{T}$ and $1.5 D_{T}$ is less than that induced in the non-grouted wall case by 11 and $15 \%$ respectively.

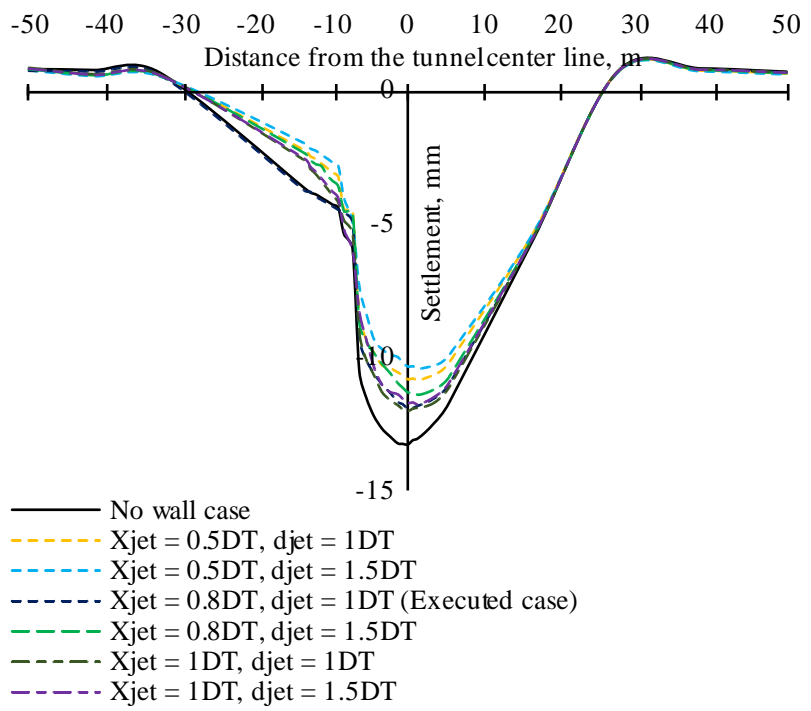

Figure 11. Induced surficial settlement for different $X_{\text {jet }}$ and $d_{j e t}$ of the grouted wall relative to $D_{T}$

Also, the results indicate that, as the grouted wall distance $\left(X_{j e t}\right)$ gets closer to the tunnel, the surface settlement decreases due to the existence of the grouted wall in the zone of higher ground movements near the tunnel opening.

Further, the grouted wall tip located below tunnel springline of the length equal or more than $1 D_{T}$ with tangent surface to the tunnel vicinity is an effective protecting technique in reducing surface settlement by $22 \%$ lower than that in- duced in the non-grouted wall case. By comparing the results of induced surface settlement, it can be outlined that there is no significant change in surficial settlement when utilizing a grouted wall located at a distance more than $0.8 D_{T}$ irrespective of the wall length.

Figures 12 and 13 show the induced axial force deve-loped on the nearest pile and partition wall vertical stress due to tunneling process, respectively. This computed axial force is recorded for different offset values and lengths of the grouted wall due to tunneling in association with no grouted wall case.

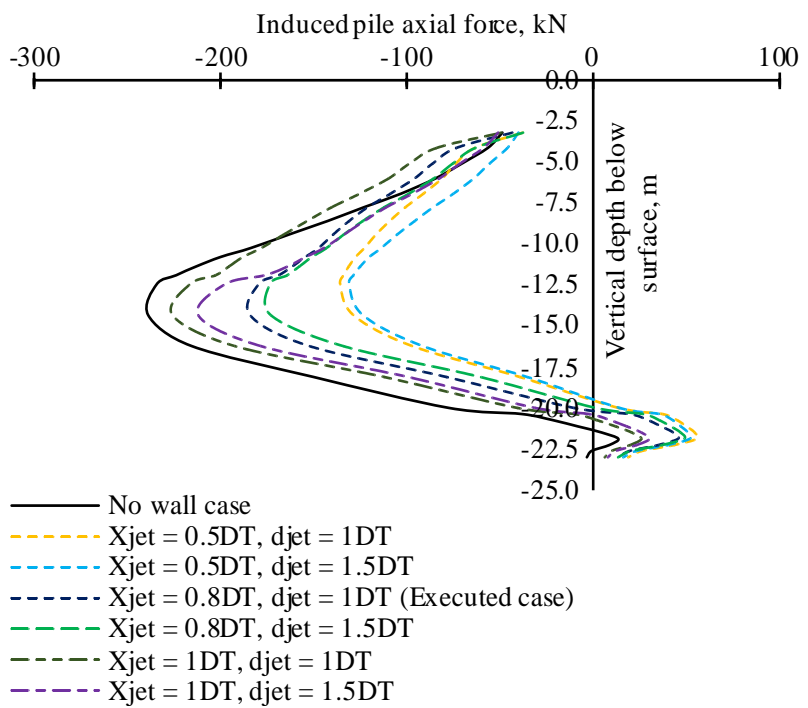

Figure 12. Induced pile axial force for different $X_{j e t}$ and djet of the grouted wall relative to $D_{T}$

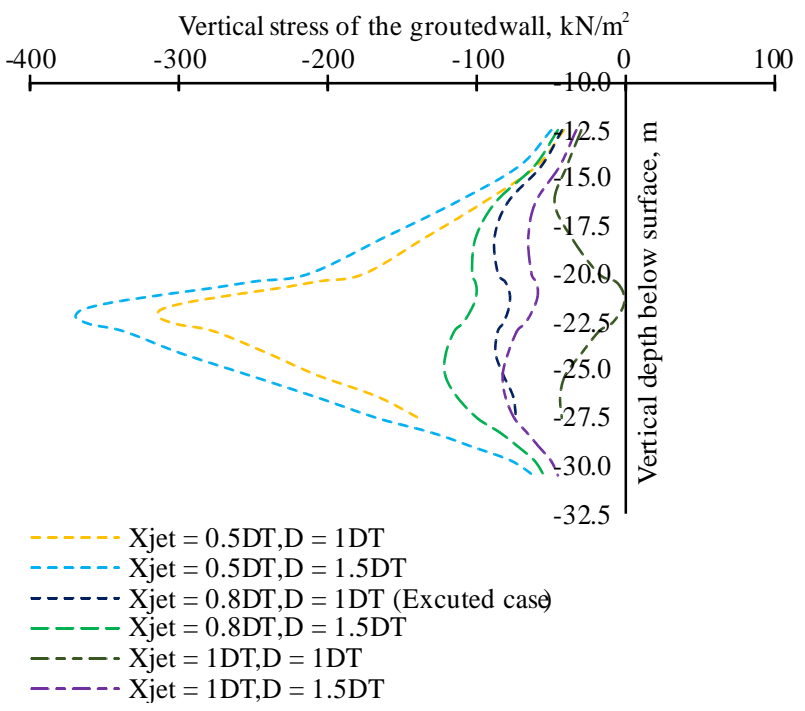

Figure 13. The induced vertical stress for the grouted wall for different $X_{\text {jet }}$ and djet relative to $D_{T}$

Generally, the axial force along the pile shaft increases as a result of tunnel construction. Inclusion of the underground wall causes reduction in the induced axial force. The maximum reduction is found to be at wall length $\left(d_{\text {jet }}\right)$ more than $1 D_{T}$ from the tunnel springline as shown in Figure 12. That can be attributed to the developing of large dragging force from tunneling along the wall length which is redistributed and transmitted in small amount by interaction mechanism to the soil, and hence, the axial force developed along the pile decreases. 
The maximum axial force is observed at a level relatively above the tunnel springline, where the maximum soil movement occurs to fill the gap between the tunnel and the soil. In other words, the inclusion of the partition wall could redistribute the loading force. The force generated from tunneling is a downward dragging force in the region above the tunnel springline, whereas the soil below the tunnel will produce an upward force. These two oppositely directed friction forces meet at the neutral point of the tunnel height and hence lead to the maximum internal axial force at some point of the pile length above the tunnel springline.

Generally, the nearest grouted wall $X_{j e t}=0.5 D_{T}$ reduces the dragging force on the pile greatly - by about $46 \%$, and $18 \%$ of that in case of no grouted wall and the executed case respectively.

Furthermore, there is inverse proportion between the axial force carried by both the grouted wall and the existing pile as seen in Figure 13. From studying closely the vertical stress variation along the grouted wall, it can be seen that for larger spacing between the grouted wall and the tunnel, no arch action is developed and hence less load is transferred from the tunnel to the body of the wall and vice versa in case of the nearest wall location to the tunnel.

It is realistic that the axial force induced on the pile is controlled by the induced stress in the soil as a result of skin friction between them. Thus, employing the grouted wall adjacent to the tunnel opening reduces the force transferred to the surrounding soil and consequently to the embedded pile.

On the other hand, the effect of a long partition wall $\left(d_{j e t}>1 D_{T}\right)$ is clearly dominant in reducing the induced vertical settlement of the nearest pile as outlined in Figure 14.

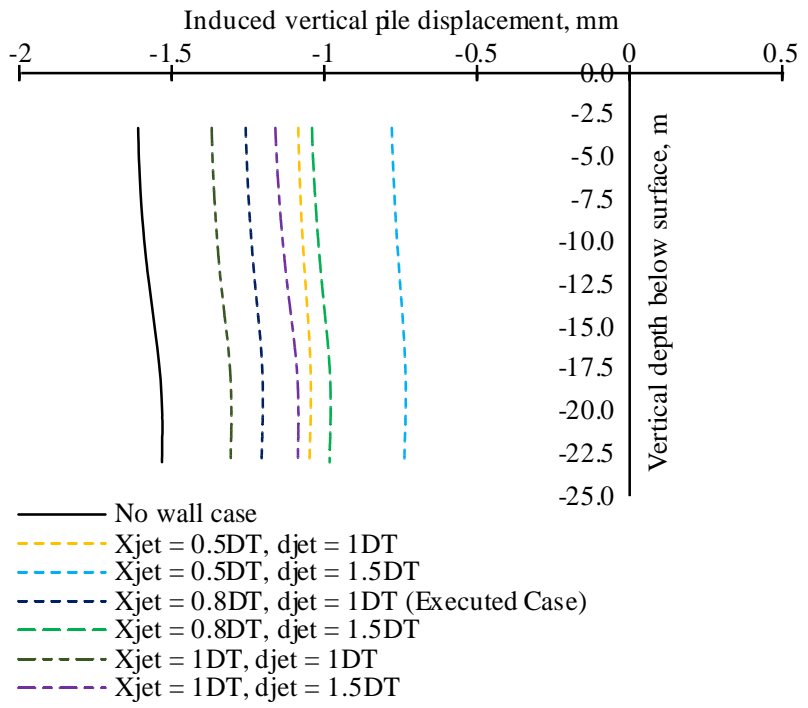

Figure 14. Induced pile displacement for different $X_{j e t}$ and $d_{j e t}$ of the grouted wall relative to $D_{T}$

This should be due to the fact that the invert displacement was assumed to be zero, and the deformation below the tunnel invert level should be very small. Hence, the barrier effect of the partition wall is considered fixed to some extent. So, the presence of a long underground partition wall can sustain the large displacement resulting from tunneling. This movement is great due to downward displacement caused by tunnel excavation.

Generally, the pile experienced almost uniform vertical displacement along its length. This may be attributed to the large pile stiffness and its tip located above the tunnel invert level. Accordingly, the pile follows the soil movement developed due to the tunnel excavation. This observation is confirmed and documented by Vermeer and Bonnier [13] and $\mathrm{Fu}$ et al. [7].

For the grouted wall installed deeper $\left(d_{j e t}=1.5 D_{T}\right)$ and located close to the tunnel circumference or mid-way between the pile and the tunnel $\left(X_{j e t} \leq 0.8 D_{T}\right)$, the pile displacement reduces significantly by about $48 \%$, and $65 \%$ less than that induced in the case of non-grouted wall respectively.

Figures 15 and 16 outline the induced bending moment and horizontal displacement developed on the nearest pile due to tunneling process respective to different offset values and lengths of the grouted wall in comparison with the nongrouted wall case.

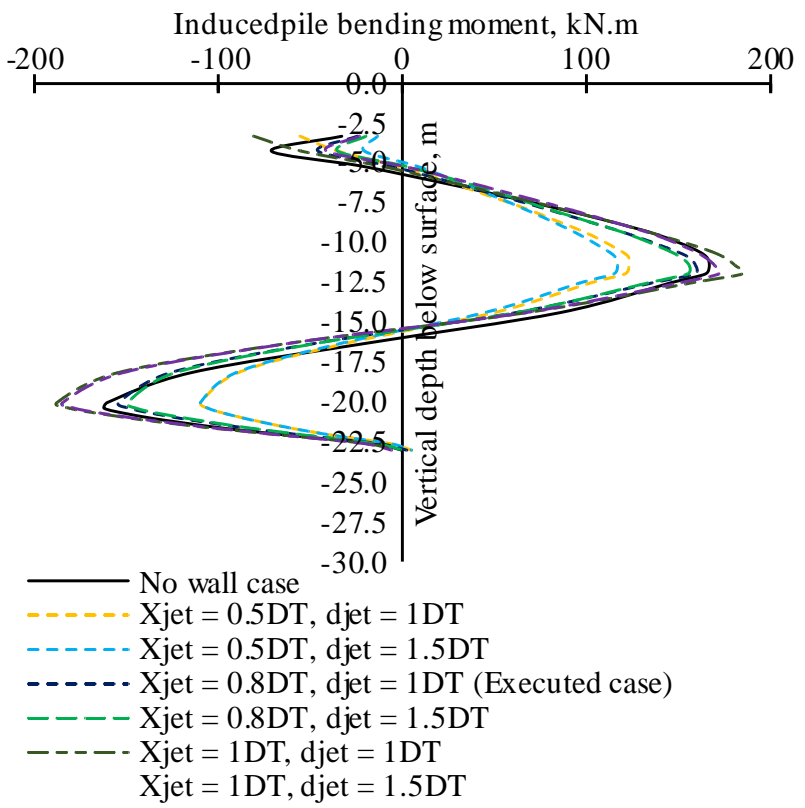

Figure 15. Induced pile bending moment for different $X_{j e t}$ and $d_{j e t}$ of grouted wall relative to $D_{T}$

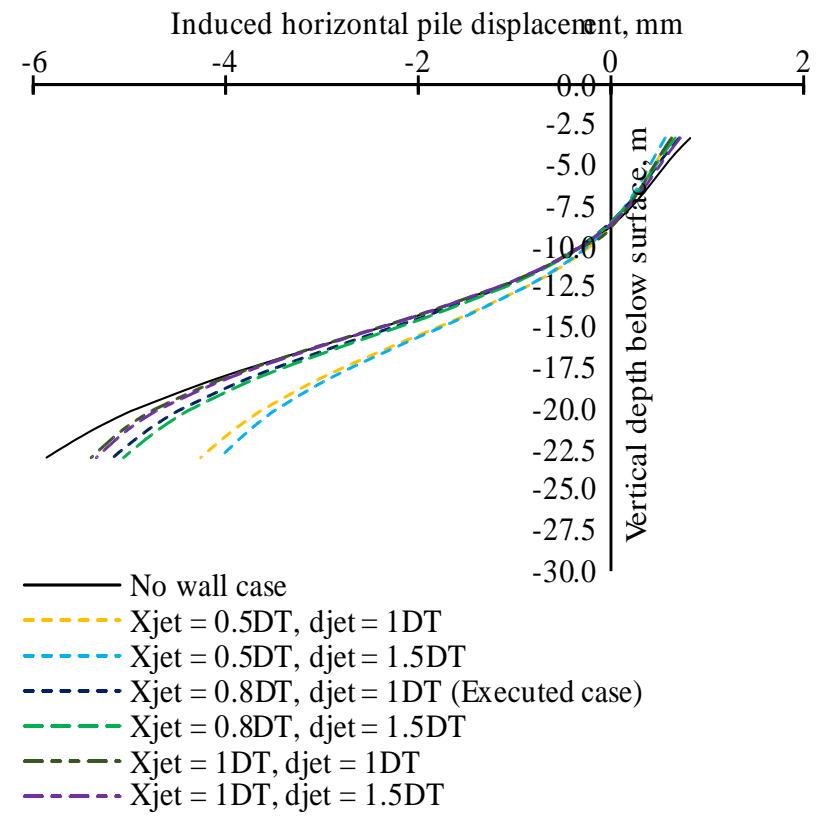

Figure 16. Induced horizontal pile displacement for different $X_{j e t}$ and $d_{j e t}$ of grouted wall relative to $D_{T}$ 
It is apparent that the tunnel excavation causes an increase in bending moment along the pile shaft. Great increase in the pile bending moment occurs at the level of the tunnel springline, while a large movement occurs in the tunnel lining due to the overburden pressure. In addition, the bending moment is maximum in the middle of the pile as a result of restriction by the pier of the viaduct. By comparing the induced bending moment developed along the pile shaft, it can be observed that for same wall location there is no change in the pile bending moment values either for the short grouted wall $\left(d_{j e t}=1 D_{T}\right)$ or long grouted wall $\left(d_{j e t}=1.5 D_{T}\right)$ cases.

Minimum bending moment induced on the pile is detected when the grouted wall offset distance is $X_{j e t}=0.5 D_{T}$ and increases as the grouted wall offset distance increases. On the other hand, employing grouted wall at a distance more than $0.8 D_{T}$ is not effective in shielding the piles from tunneling effect, and there is an increase of induced bending moment value along the pile shaft more than that induced in the no grouted wall case. This increase in bending moment is due to reduction in percentage of stress carried by the wall. This reduction in axial force carried by the wall leads to an increase in the active pressure transferred to the body of the pile from tunneling, beside the arch action developing between the wall and the pile, which increases the ability of transferring the lateral displacement of the wall to the body of the pile.

Reduction in bending moment always means reduction in lateral displacement. This can be detected for the long grouted wall nearest to the tunnel opening $\left(X_{\text {jet }}=0.5 D_{T}\right.$, $d_{j e t}=1.5 D_{T}$ ), the horizontal displacement of the pile tip being reduced greatly - to the value by about $50 \%$ less than in the no grouted wall case. This can be attributed to the confining effect of the long wall restraining the lining deformation, as it tends to change from circular cross section to oval shape due to the weight of the overburden soil pushing the pile tip away from the tunnel. However, there is no significant difference between the distributions of the maximum displacements induced along the pile front. When the offset distances varied between $0.8 D_{T}$ to $1 D_{T}$. the upper part of the piles deflected towards the tunnel, while the pile tip located near the tunnel springline deflected in the opposite direction with maximum deflection as shown in Figure 16.

However, the maximum lateral deformation of the nearest pile is founded to be $6.1 \mathrm{~mm}$ in case of non-grouted wall. Referring to the Technical Code for Building Pile Foundation JGJ 94 [14], the lateral deformation of the pile foundation of a sensitive building should not exceed $6 \mathrm{~mm}$, and the lateral deformation of the pile foundation of a general building should be less than $10 \mathrm{~mm}$. It means that the lateral deformation of some piles has exceeded the alarm value stipulated in the code, and these piles would be in a critical stability condition. Therefore, it is necessary to take some mitigation measures to protect the piles.

Figure 17 shows the effect of the wall configuration contribution on the induced behavior in terms of axial force, vertical displacement, bending moment, and lateral displacement of the nearest pile.

The minimum generated stress on the pile is observed in cases when a high percentage of axial force, vertical displacement, bending moment and lateral displacement are carried by the grouted wall. Besides, conducting the grouted wall at small offset from the pile cap is not effective in shielding the piles from the tunnel induced stress. (a)

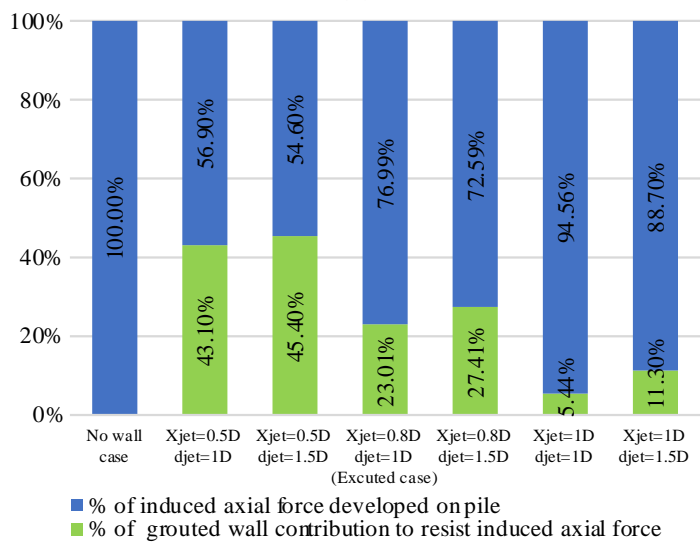

(b)

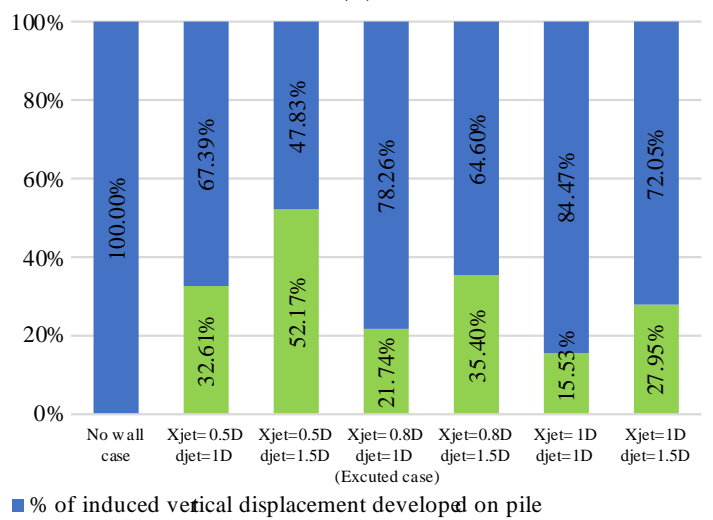

= \% of grouted wall contribution to resist induced vertical disphcement

(c)

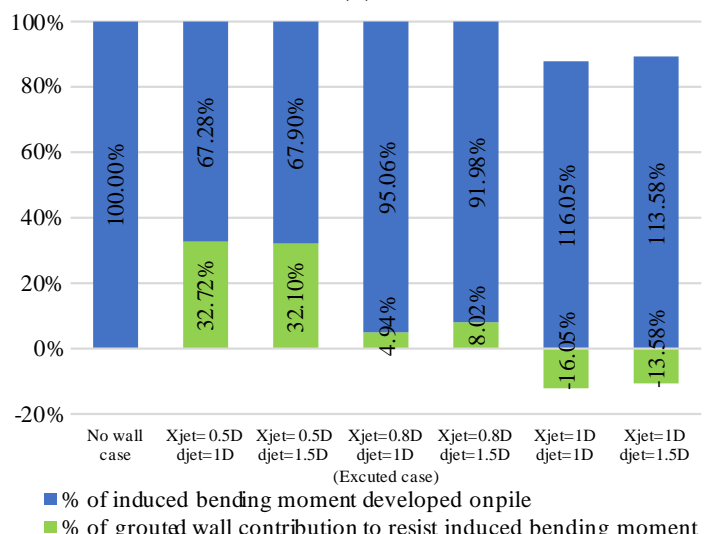

(d)

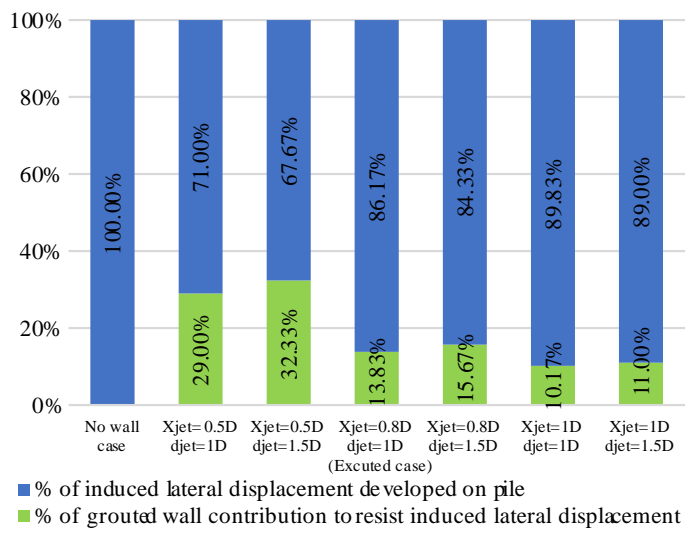

Figure 17. \% of the grouted wall contribution to resist the induced: (a) axial force; (b) vertical displacement; (c) bending moment; (d) horizontal displacement which developed on the nearest pile 
As a result of small spacing, an arch is developed and consequently increases the ability of the structure to transfer the load to the body of the nearby grouted wall. These results emphasize that the underground partition wall can work effectively in improving the efficiency of the pile-pier interaction, which would be affected by the nearby tunnel excavation.

\subsection{Effect of jet grouted wall thickness}

Besides the grouted wall thickness relative to jet grouted column diameter $B_{j e t}=1.8 \mathrm{~m}\left(2.25 d_{g c}\right)$, which represents (Executed case), an additional analysis with the grouted wall thickness $\left(B_{j e t}\right)$ of $1.5 \mathrm{~m}\left(1.8 d_{g c}\right)$, and $2 \mathrm{~m}\left(2.5 d_{g c}\right)$ was carried out to investigate the effect of the grouted wall thickness on ground settlement and the pile. Figure 18 shows the induced surficial settlement trough obtained for the grouted wall thickness relative to jet grouted column diameter. It can be observed that a slight difference between the two cases of the grouted wall thickness $B_{j e t}=(2.25$ or 2.5$) d_{g c}$ is insignificant.

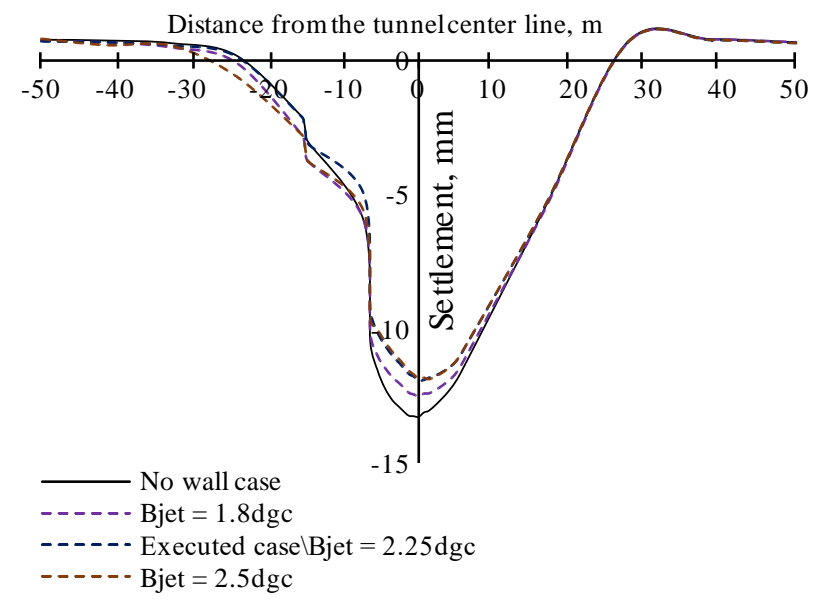

Figure 18. Induced surficial settlement for different $B_{\text {jet }}$ relative to the grouting column

However, it is obvious that the wall thickness will affect the efficiency of the underground wall, while further increase in the wall thickness more than twice jet grouted column diameter shows little effect on the efficiency of the partition wall.

Figure 19 shows the induced axial force on the nearest pile due to tunneling process. The same criteria of small difference between the values of axial force are observed along the pile shaft with respect to different grouted wall thicknesses.

However, increasing grouted wall thickness by about $11 \%$ or reducing it by $20 \%$ of the executed case show a little effect on the axial force developed along the pile. Also, the same trend is shown for the induced pile vertical displacement as shown in Figure 20. From the economic perspective, increasing wall thickness more than double the grouted column diameter is not effective. Also, the bending moment and lateral displacement values developed along the pile shaft change slightly irrespective of increasing grouted wall thickness as shown in Figures 21 and 22 respectively.

\subsection{Effect of mechanical properties of the jet grouted wall}

The effect of grouting can be recognized as increase in the soil stiffness and shear parameters. Tan and Clough [15] studied utilization of grouting in tunnels, and the scale of the effect of grouting on sandy soil properties.

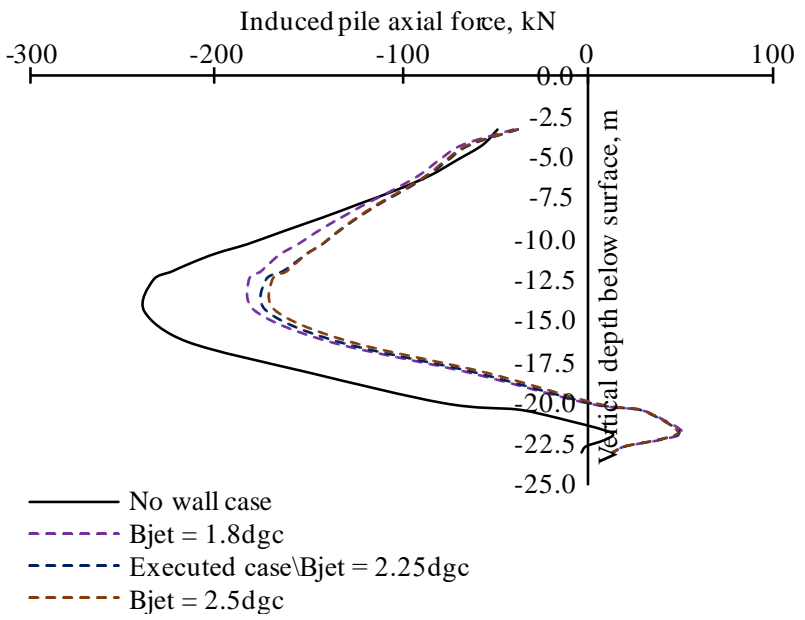

Figure 19. Induced pile axial force for different $B_{j e t}$ relative to $d_{g c}$

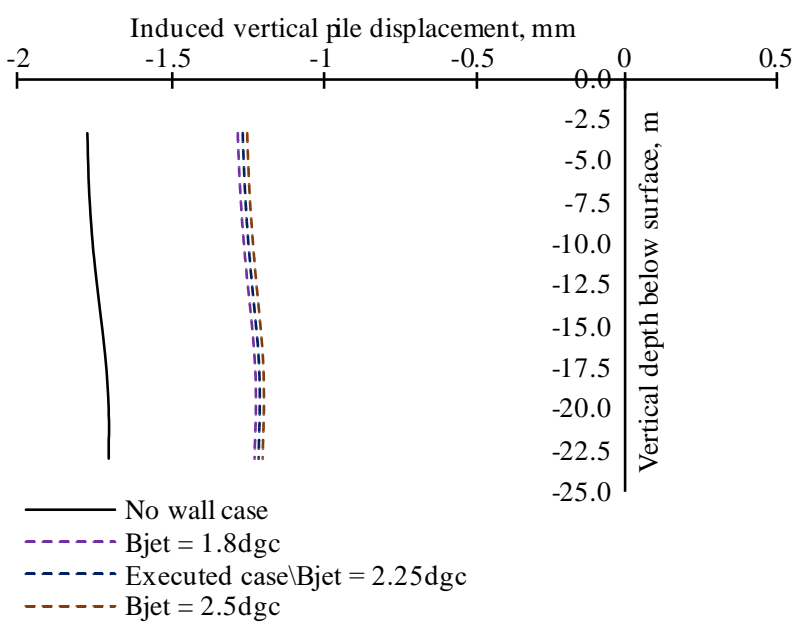

Figure 20. Induced pile vertical displacement for different $\boldsymbol{B}_{j e t}$ relative to $d_{g c}$

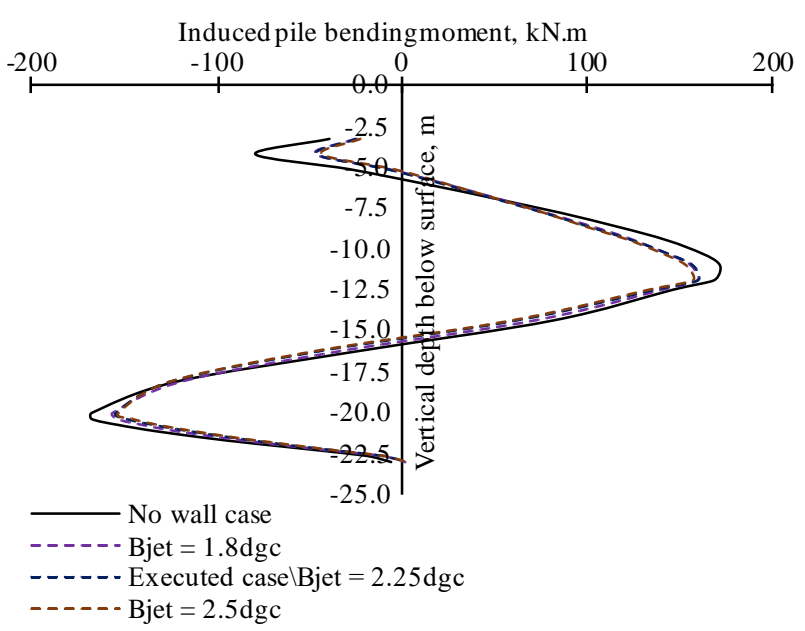

Figure 21. Induced pile bending moment for different $B_{j e t}$ relative to $d_{g c}$

They enumerated some projects where injection proved to be a very beneficial practice during construction of tunnels. The stiffness of the grouted wall depends on the stiffness of soil to be improved. Besides, $E_{\text {grout }}=40 E_{\text {soil }}$ which represents the executed case. Additional analysis with the grouted wall stiffness 20 and 60 times $E_{\text {soil }}$ is encountered which simulated by two constitutive model Mohr-Coulomb and elastic criterion. 


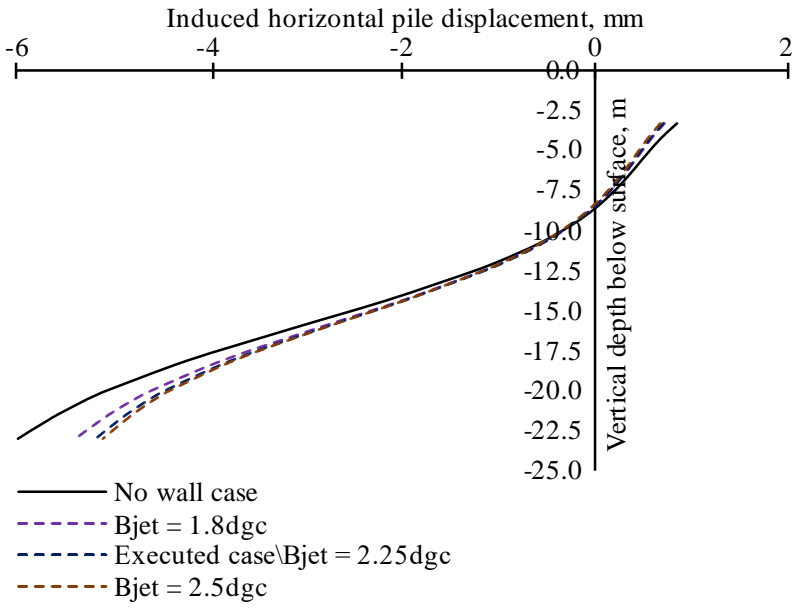

Figure 22. Induced horizontal pile displacement for different $\boldsymbol{B}_{j e t}$ relative to $d_{g c}$

For Mohr-Coulomb criterion, Bell [16] showed that the change in the angle of friction $(\varphi)$ of sandy soil caused by grouting is generally insignificant. the cohesion of the grouted soil can be estimated (assuming no change in the frictional angle of the stabilized soil), from Equation 2:

$$
C_{\text {grout }}=\frac{q_{\text {un }}}{2 \tan \left(45^{\circ}+\frac{\varphi}{2}\right)}
$$

Young's modulus of the grouting presented as a function of the weight density and design criteria strength in the concrete design specification Song, et al. [17] as given by Equation 3:

$$
E_{\text {grout }}=W \cdot 4270 \cdot \sqrt{q_{\text {un }}} \text {. }
$$

Adopting Mohr coulomb as material type is considered the best numerical simulation of grouted wall properties. The Mohr-Coulomb give the shear strength that depends on the confining pressure and can give tensile strength if the friction angle is not zero. Otherwise, the suggestion of employing elastic criterion is just simplification techniques in numerical model.

The present study ignores such simplification and focusing on the effect of grouting in increasing stiffness and strength of the grouted soil. these two different material types are considered for the executed case.

Table 3 summarizes all mechanical properties used in adopting the stiffness of jet grouted wall based on soil stiffness by considering Mohr column and elastic criterions.

Table 3. Mechanical properties of jet grouted wall for each case

\begin{tabular}{cccc}
\hline No. & Type & Case & Properties \\
\hline 1 & No wall case & No jet grouted wall case \\
\hline 2 & & $E_{\text {jet }}=20 E_{\text {soil }}$ & $E=1 \times 10^{3} \mathrm{MPa}, v=0.2$ \\
3 & Elastic & $E_{\text {jet }}=40 E_{\text {soil }}-$ & $E=2 \times 10^{3} \mathrm{MPa}, v=0.2$ \\
4 & & Executed case & \\
& & $E_{\text {jet }}=60 E_{\text {soil }}$ & $E=3 \times 10^{3} \mathrm{MPa}, v=0.2$ \\
\hline 5 & & $E_{j e t}=20 E_{\text {soil }}$ & $E=1 \times 10^{3} \mathrm{MPa}, v=0.2$, \\
& & $C=57 \mathrm{kPa}, \varphi=36^{\circ}$ \\
6 & Mohr- & $E_{j e t}=40 E_{\text {soil }}$ & $E=2 \times 10^{3} \mathrm{MPa}, v=0.2$, \\
& Coulomb & $C=226 \mathrm{kPa}, \varphi=36^{\circ}$ \\
7 & & $E_{j e t}=60 E_{\text {soil }}$ & $E=3 \times 10^{3} \mathrm{MPa}, v=0.2$, \\
& & & $C=510 \mathrm{kPa}, \varphi=36^{\circ}$ \\
\hline
\end{tabular}

From Figure 23 it can show that there no significant effect of the jet grouted wall stiffness on surficial surface settlement regardless the type of material.

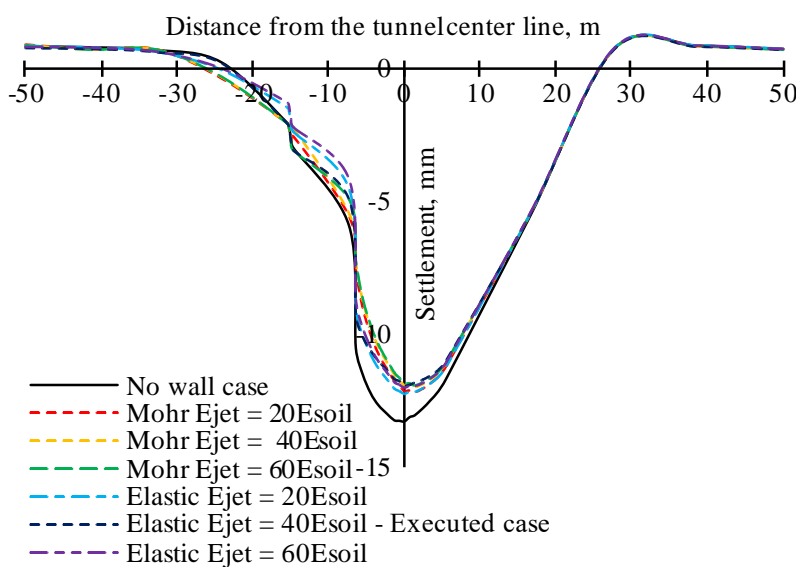

Figure 23. Induced surficial settlement for different stiffness of grouted wall

Figure 24 demonstrated the variation of axial load along pile shaft for different wall material properties. It can be observed that the minimum values of axial force are generated in cases of employing the Mohr-Coulomb criterion regardless of the value of young's modules.

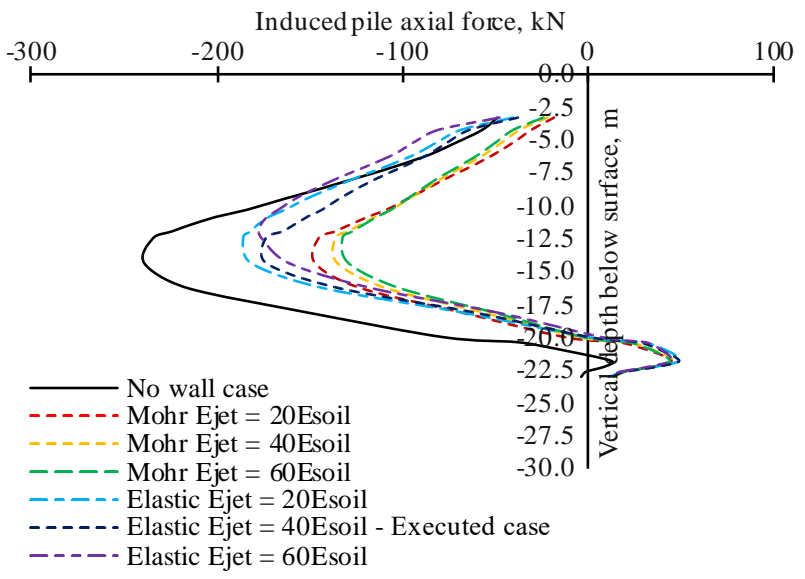

Figure 24. Induced pile axial force for different stiffness of grouted wall

This can be attributed to increasing grouping action in case of employing the approximation of elastic grouted wall and hence increasing stress bulb in zone between pile and wall. While the wall stiffness in case of applying MohrCoulomb material is giving high plasticity behavior to absorb the dragging force resulted from tunnel excavation. However, to be conservative, the generated axial force along pile shaft is less than that developed in the no grouted wall case by 38,43 and $44 \%$ in cases $E_{j e t}=(20,40$ and 60$)$ times soil young modulus, respectively.

Figure 25 demonstrates the induced vertical displacement along pile shaft. It is realistic that minimum pile settlement is detected in cases of conducting grouted wall with high young's modulus values $\left(E_{j e t}>20 E_{\text {soil }}\right)$ irrespective to material type.

Figures 26 and 27 show the induced bending moment and lateral displacement on the adjacent pile to the tunnel route. 


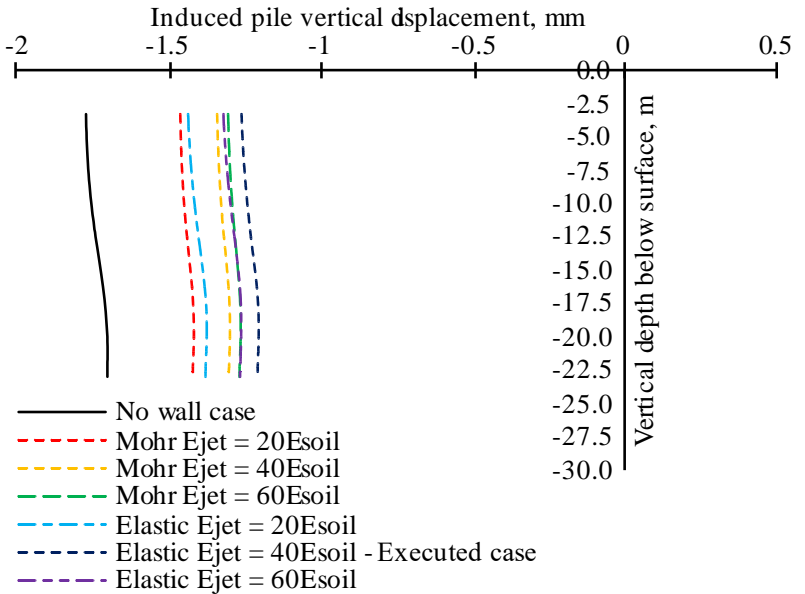

Figure 25. Induced pile vertical displacement for different stiffness of grouted wall

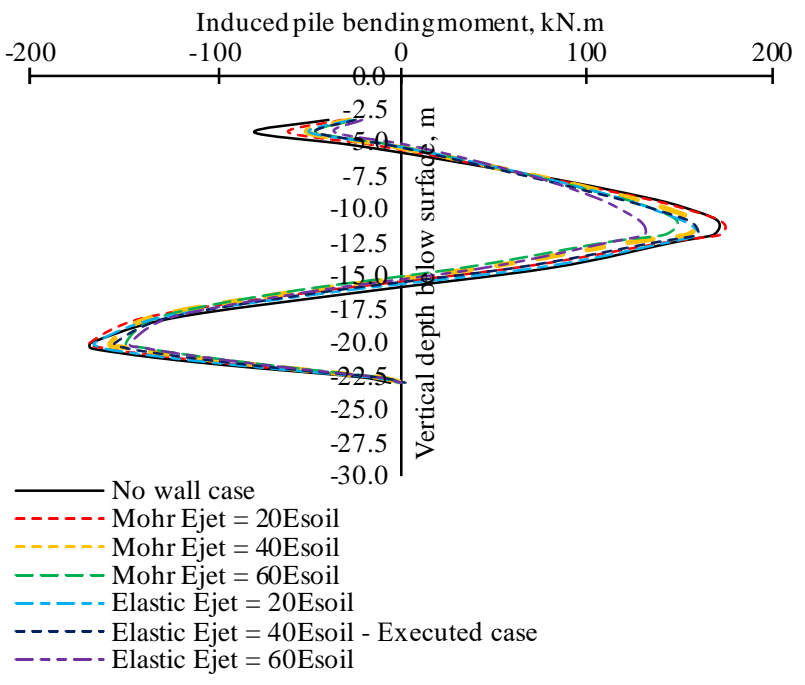

Figure 26. Induced pile bending moment for different stiffness of grouted wall

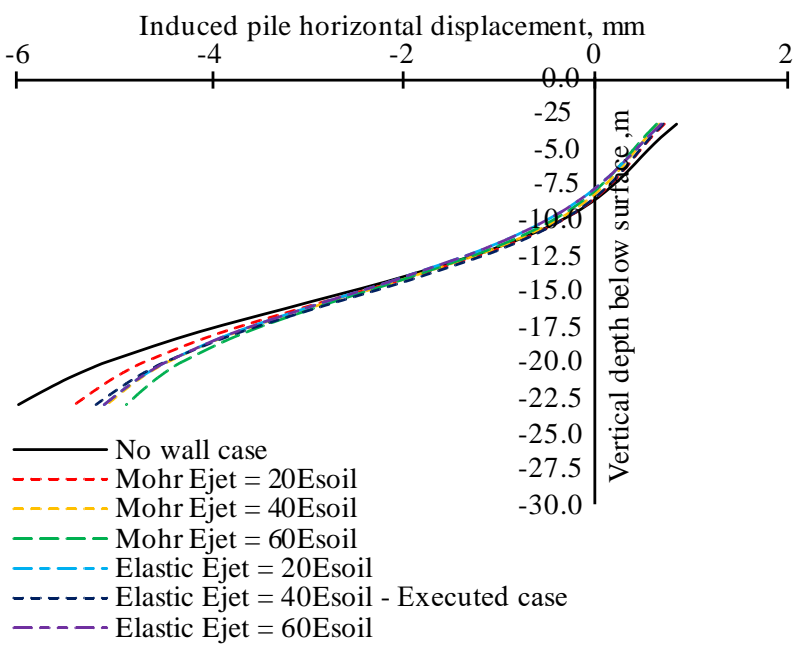

Figure 27. Induced horizontal pile displacement for different stiffness of the grouted wall

It can be seen that either adopting elastic or mohrcoloumb to be employed as wall material in Abaqus program have no effect on induced bending and lateral displacement of pile regardless of young's modulus.

\subsection{Effect of friction coefficient for jet grouted wall}

ABAQUS interface element is used to reproduce wallsoil contact. The interfaces between the grouted wall and the soil were modeled with surface-to-surface contact. This contact is defined by normal $\left(K_{n}\right)$ and tangential coefficient $\left(K_{s}\right)$ which reduces the strength and stiffness parameters of the surrounding soil. The behavior of the interfaces employing the Coulomb friction criterion with the friction coefficient of smooth, 0.5, 0.8, and rough for wall-soil interface.

Figure 28 shows that there is no significant effect of the increasing or decreasing friction coefficient on the surface settlement.

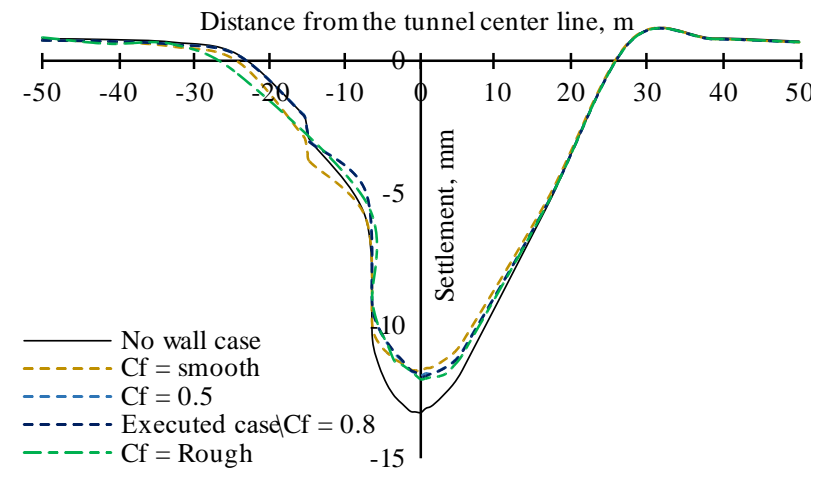

Figure 28. Induced surficial settlement for different friction coefficient

Figures 29 shows percentage of reduction for induced axial force, vertical displacement, bending moment and horizontal displacement developed on the pile shaft as a ratio of that developed in no grouted wall case with respect to different friction coefficient between the grouted wall and the surrounding soil.

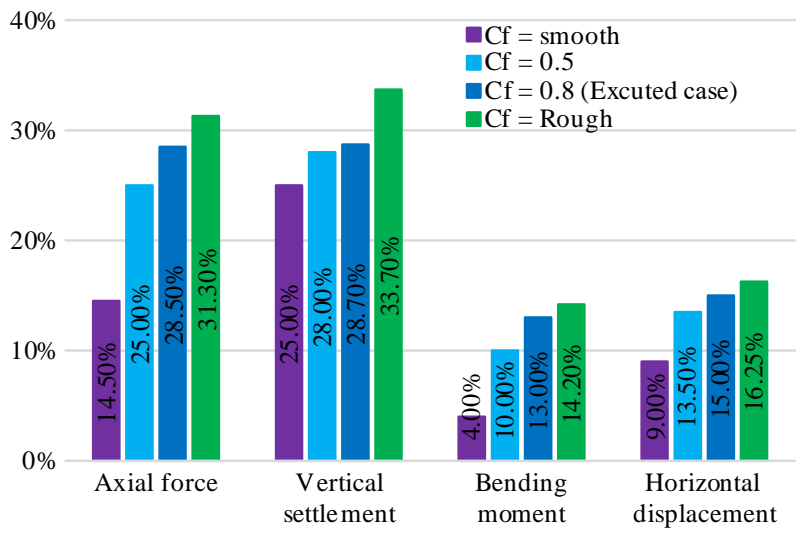

Figure 29. \% of reduction in friction coefficient for axial force, vertical displacement, bending moment and horizontal displacement developed on the pile shaft with respect to no wall case

Reduction in friction coefficient leads to increase in the settlement of the grouted wall relative to the surrounding soil. Also, this reduction in friction coefficient will reduce the capability of the grouted wall to carry the induced axial force from tunneling. So, the large part of the transmitted dragging force is transferred from the tunnel to the surrounding soil. Accordingly, the induced axial force along the pile increases, the same result being documented by Fantera et al. [18]. 
To conclude, the increase in the grouted wall length offers a longer portion of the wall for the development of the shear stresses - making them reach lower values, consequently, the mobilized shear strength decreases, and the influence of the wall roughness becomes less important.

\section{Summary and conclusions}

The performance of a jet-grouted wall in mitigating the effects of tunneling on an adjacent pile-supported pier was compared with field measurements by developing a numerical model using the finite element program ABAQUS 2016. The modelling shows the ability of ABAQUS software to simulate the complex soil - pile - grouted wall - tunnel interaction problems.

Furthermore, a set of parametric studies for jet grouted wall including length, location with respect to the tunnel route, thickness, mechanical properties, and friction coefficient with surrounding soil is conducting with the same model scheme of the verified case. The following can be concluded from this study in the next section. The results of the parametric studies are presented in the form of charts. Modeling of complicated interaction features is a typical 4D problem in which the details of the tunneling activities regarding to time is simulated. The parameters adopted in tunneling simulation and depending on time is face pressure, rate of tunnel advance, machine overcutting, developed gap, lining erection, and tail grouting.

1. The calculation results show that the overall settlement of the ground and piles foundations of the viaduct is large during shield tunneling without the protective scheme. Therefore, protective schemes of shield tunneling are carried based on the response in three aspects: disturbance source, transfer medium, and disturbance object.

2. Generally, the efficiency of a partition wall can be improved by increasing the length and location of the wall. This can be seen clearly in the case of the jet grouted wall located in close distance $0.5 D_{T}$ from the tunnel centerline with embedded lengths $1 D_{T}$ or $1.5 D_{T}$. However, the effect of the wall length should be properly limited in a moderate range to make the protective measures more economical. The moderate efficiency of the grouted wall is outlined at offset distance $0.8 D_{T}$ from the tunnel and depth of penetration ranging between $1 D_{T}$ to $1.5 D_{T}$ below the tunnel springline. Further increase in these factors would lead to negligible improvement in the effectiveness, as seen by employing the grouted wall at a distance more than $0.8 D_{T}$, where there is an increase in the induced bending moment value along the pile shaft more than that induced in no grouted wall case resulting from the increase in arch action developing between the wall and the pile.

3. The effects of the jet grouted wall with the MohrCoulomb criteria generate a significant reduction in the maximum axial force in the pile, as compared to a linear elastic criterion, thereby allowing more realistic and economical predictions of pile-group responses shielded by the grouted wall.

4. By comparison, there is no significant effect on the behavior of the pile by increasing or decreasing friction coefficient even if rough between the grouted wall and the soil. So, increasing wall length is considered more effective in mitigating the tunneling effect than increasing interface friction. Besides, adopting smooth interface causes reduction between the wall and the surrounding soil, which can introduce a discontinuity in shear stress transmission, leading to an increase in ground movements, axial force, and horizontal displacement of the pile.

5. From economic perspective, increase in the wall thickness more than double grouted column diameter is not effective.

6. Locations of maximum lateral displacements and forces on the pile were close to the pile toe. This phenomenon can be attributed to the location of the pile toe slightly above the tunnel axis, where the largest horizontal soil displacement occurred.

\section{Acknowledgements}

The authors would like to thank the anonymous reviewers and the editor for their valuable comments.

\section{References}

[1] Xiang, Y. Jiang, Z., \& He, H. (2008). Assessment and control of metro-construction induced settlement of a pile-supported urban overpass. Tunneling and Underground Space Technology, 23(3), 300-307. https://doi.org/10.1016/j.tust.2007.06.008

[2] Bilotta, E., \& Russo, G. (2011). Use of a line of piles to prevent damages induced by tunnel excavation. Journal of Geotechnical and Geoenvironmental Engineering, 137(3). https://doi.org/10.1061/(ASCE)GT.1943$\underline{5606.0000426}$

[3] Ng, C.W., Lu, H., \& Peng, S.Y. (2013). Three-dimensional centrifuge modelling of the effects of twin tunneling on an existing pile. Tunneling and Underground Space Technology, (35), 189-199. https://doi.org/10.1016/j.tust.2012.07.008

[4] Zou, W.H., \& Xu, M. (2013). 3D numerical analysis of mitigation effect of separation pile and diaphragm wall considering small strain stiffness of soils. Chinese Journal of Geotechnical Engineering, (1), 203-209.

[5] Bai, Y., Yang, Z., \& Jiang, Z. (2014). Key protection techniques adopted and analysis of influence on adjacent buildings due to the Bund Tunnel construction. Tunneling and Underground Space Technology, (41), 24-34. https://doi.org/10.1016/j.tust.2013.11.005

[6] Nematollahi, M., \& Dias, D. (2019). Three-dimensional numerical simulation of pile-twin tunnels interaction - Case of the Shiraz subway line. Tunneling and Underground Space Technology, (86), 75-88. https://doi.org/10.1016/j.tust.2018.12.002

[7] Fu, J., Yang, J., Zhu, S., \& Shi, Y. (2016). Performance of jet-grouted partition walls in mitigating the effects of shield-tunnel construction on adjacent piled structures. Journal of Performance of Constructed Facilities, 31(2), 04016096. https://doi.org/10.1061/(ASCE)CF.1943-5509.0000961

[8] EL-Attar, A.N. (2018). Reducing the tunneling effect on adjacent pile foundations. Engineering Challenges for Sustainable Underground Use, 160-172. https://doi.org/10.1007/978-3-319-61636-0_13

[9] Li, P., Lu, Y., Lai, J., Liu, H., \& Wang, K (2020). A Comparative study of protective schemes for shield tunneling adjacent to pile groups. Advances in Civil Engineering, (2020), 6964314. https://doi.org/10.1155/2020/6964314

[10] Pawtucket, R.I. (2016). ABAQUS user's manual. ABAQUS Inc. Version 6.16.

[11] Moller, S. (2006). Tunneling induced settlements and structure forces in linings. Ph.D. Thesis. Stuttgart, Germany. Stuttgart University.

[12] ACI-Building-Code. (2011). ACI 318-11 Building code requirements for structural concrete and commentary. Farmington Hills, United States: American Concrete Institute.

[13] Vermeer, P.A., \& Bonnier, P.G. (1991). Pile settlements due to tunneling. Proceedings of the $10^{\text {th }}$ European Conference on Soil Mechanics and Foundation Engineering, 869-872.

[14] Technical specification for building pile foundation, geotechnical mechanics. (2008). Beijing, China: Ministry of Housing and UrbanRural Construction of the People's Republic of China.

[15] Tan, D.Y., \& Clough, G.W. (1980). Ground control for shallow tunnels by soil grouting. International Journal of Rock Mechanics and Mining Sciences \& Geomechanics Abstracts, 18(2), 36-1058. https://doi.org/10.1016/0148-9062(81)90940-2

[16] Bell, F.G. (1993). Engineering treatment of soils. London, United Kingdom: E \& FN SPON. https://doi.org/10.4324/9780203474181 
[17] Cho, G., Kim, J., \& Song, K. (2008). Analysis of pre-reinforced zone in tunnel considering the time-dependent performance. Geotechnical Aspects of Underground Construction in Soft Ground. https://doi.org/10.1201/9780203879986.ch99

Чисельний аналіз зменшення впливу проходки на основі свай віадука, залитих струменевим розчином

\section{К. Аскер, М.Т. Фуад, М. Бахр, А. Ель-Аттар}

Мета. Виконати чисельне моделювання опису процесу проходки тунелю, а також вивчення механізмів взаємодії між тунелем, способом кріплення та підошвою за допомогою аналізу різних конфігурацій кріплення з урахуванням різної міцності залитої цементним розчином стіни й застосування різних коефіцієнтів межі розділу між стіною і підошвою.

Методика. Для перевірки точності запропонованої чисельної моделі використовувалася програма 4-D ABAQUS. Проходка тунелю моделюється покроково при передбачуваній швидкість проходки від 0.5 до 1.5 м/год. Дана модель розглядає матеріал підошви як еластичний ідеально пластичний (за критерієм Мора-Кулона). Еластичний матеріал представлений в моделі як тверда речовина (S4R), що використовується для оброблення, цементування, заповнення пустот, щитової проходки, спорудження свай та залитих струменевим розчином стінок.

Результати. Результати дослідження свідчать про те, що чим ближче розташована установка струменевої цементації до тунелю, довжина якого в півтора рази більше його діаметра, тим більший вплив вона чинить на зменшення бічних деформацій і згинальні моменти свай. Встановлено, що збільшення товщини стінок до величини, що вдвічі перевищує діаметр залитих струменевим розчином свай, не впливає на їх захисну здатність. Крім того, ні збільшення, ні зменшення коефіцієнта тертя між залитою цементним розчином стіною і підошвою не чинить істотного впливу на поведінку свай. Застосування критерію Мора-Кулона для високоміцної зацементованої струменевим розчином стіни дозволяє реалістично оцінити реакцію групи свай.

Наукова новизна. Надійність даної моделі підтверджена зворотним аналізом в рамках проекту 1-й лінії метро Чанши, згідно 3 яким тунель буде побудований методом щитової проходки навколо існуючих груп опор на L з’їді 3 віадука траси Ксінжонг.

Практична значимість. Зміцнена структура зацементованої стінки дозволяє зменшити вплив проходки тунелю на сваї та підвищити надійність і стійкість споруди.

Ключові слова: проходка, струминне иементування, польові виміри, ABAQUS, 1-иа лінія метро Чанши

\section{Численный анализ уменьшения воздействия проходки на основание свай виадука, залитых струйным раствором}

\section{К. Аскер, М.Т. Фуад, М. Бахр, А. Эль-Аттар}

Цель. Выполнить численное моделирование описания процесса проходки тоннеля, а также изучение механизмов взаимодействия между тоннелем, способом крепления и грунтом посредством анализа разных конфигураций крепления с учетом различной прочности залитой цементным раствором стены и применения различных коэффициентов границы раздела между стеной и почвой.

Методика. Для проверки точности предложенной численной модели использовалась программа 4-D ABAQUS. Проходка тоннеля моделируется пошагово при предполагаемой скорости проходки от 0.5 до 1.5 м/час. Данная модель рассматривает материал грунта как эластичный идеально пластичный (по критерию Мора-Кулона). Эластичный материал представлен в модели как твердое вещество (S4R), используемое для обделки, цементирования, заполнения пустот, щитовой проходки, сооружения свай и залитых струйным раствором стенок.

Результаты. Результаты исследования свидетельствуют о том, что чем ближе расположена установка струйной цементации к тоннелю, длина которого в полтора раза больше его диаметра, тем большее влияние она оказывает на уменьшение боковых деформаций и сгибающего момента свай. Установлено, что увеличение толщины стенок до величины, вдвое превышающей диаметр залитых струйным раствором свай, не влияет на их защитную способность. Кроме того, ни увеличение, ни уменьшение коэффициента трения между залитой цементным раствором стеной и грунтом не оказывает существенного влияния на поведение свай. Применение критерия Мора-Кулона для высокопрочной зацементированной струйным раствором стены позволяет реалистично оценить ответную реакцию группы свай.

Научная новизна. Надежность данной модели подтверждена обратным анализом в рамках проекта 1-й линии метро Чанши, согласно которому тоннель будет построен методом щитовой проходки вокруг существующих групп опор на L съезде с виадука трассы Ксинжонг.

Практическая значимость. Упрочненная структура зацементированной стенки позволяет уменьшить воздействия проходки тоннеля на сваи и повысить надежность и устойчивость сооружения.

Ключевые слова: проходка, струйное чементирование, полевые замеры, ABAQUS, 1-я линия метро Чании 